\title{
Effects of Amending Materials on Seed Germination in Saline Environment
}

\author{
Gholamhossin Shokohifard, Kan-ichi Sakagami, Ryunosuke Hamada \\ and Satoshi Matsumoto* \\ Faculty of Agriculture, Tokyo University of Agriculture and Technology, \\ Fuchu 183, Japan \\ *Faculty of Agriculture, The University of Tokyo, Bunkyo-ku, Tokyo 113, Japan
}

(Received February 29, 1988)

\begin{abstract}
The effects of various amending materials on seed germination in saline environment, and the related mechanism were studied. The seed germination tests were considered as bioassay for treatment efficiency under salinity stress. The tests were carried out in petri dishes, at $25^{\circ} \mathrm{C}$ in the dark for 5 days. Generally organic materials more efficiently reduced the toxic effects of the salt than inorganic materials did. Of organic materials, farm yard manure of 3-4 months decomposition period, and of inorganic materials, Kanuma soil were the most effective ones. The effective materials deactivated considerable amount of ion $(\mathrm{Na})$ through ion holding mechanism.
\end{abstract}

\section{INTRODUCTION}

When sodium ion penetrates into the protoplasm and replaces ions that are essential, sodium injury occurs to plant. ${ }^{1)}$ Excess accumulation of ions in plant system, which causes growth suppression, reduction in yield and alteration of metabolic reaction is well documented. ${ }^{2-4}$ ) Most of the salt stresses in nature are due to sodium salts, particularly sodium chloride. ${ }^{1)}$ This problem is more serious in arid regions where excessive amount of exchangeable $\mathrm{Na}$ presents in the soil. ${ }^{5)}$ If a dynamic balance between ion concentrations within the plant cells and that in its environment is adjusted, the chance of survival of crop under saline condition is increased.

The objective of this study was to establish a rapid and simple routine method for studying i) salinity tolerance of seeds, ii) selecting the suitable amending materials which effectively reduce the salinity hazard, iii) to investigate the mechanism by which the selected effective materials reduce the salinity hazard.

\section{MATERIALS AND METHODS}

The seed germination tests were carried out on following amending materials as seed beds.

\section{Organic materials}

Decomposed (3 months) cow and horse manure, and leaf litter of Zelkova serrata, prepared in Tokyo University of Agriculture and Technology farm, and commercially available farm yard manures of various decomposition period were obtained from 
Hoyubussan Co., Chiba, dried and passed through a $2 \mathrm{~mm}$ sieve.

Gum tragacanth is a dried gummy exudation from Astragalus gummifer which is a small thorny semidesert shrub found largely in Iran. The gum is mixture of tragacanthic acid and a neutral polysaccharide, with an acidic reaction. One gram of it requires $0.9 \mathrm{ml}$ of $0.1 \mathrm{~N} \mathrm{NaOH}$ for neutralization to phenolphthalein. In presence of water it swells and forms a gel. Its sedimentation molecular weight is about 840,000. The material was ground and passed through a $2 \mathrm{~mm}$ sieve. sieve.

Filter paper sheets were boiled, disrupted, dried and passed through a $2 \mathrm{~mm}$

Materials with high initial Na content such as farm manure, commercial manures, and farm litter were washed (shaken for $1 \mathrm{~h}$ ) with 20 times of $1 \mathrm{~m}$ ammonium acetate solution ( $\mathrm{pH} \mathrm{7),} \mathrm{then} \mathrm{washed} \mathrm{with} \mathrm{water,} \mathrm{dried,} \mathrm{and} \mathrm{used} \mathrm{(Table} \mathrm{1).}$

\section{Inorganic materials}

Sub soil (C horizon) of brown forest soil of Kusaki area, Gunma prefecture, sub and top forest soils of volcanic ash origin from Tokyo University of Agriculture and Technology farm, and allophane rich soil (Kanuma) of Tochigi prefecture were sampled, dried and passed through a $2 \mathrm{~mm}$ sieve.

Sand, kaolin and bentonite were bought from Kukita Yakuhin Kogyo Co., Tokyo (Table 2).

Table 1 Some of properties of the organic materials used.

\begin{tabular}{lrrrrrrc}
\hline \multicolumn{1}{c}{ Materials } & $\begin{array}{c}\mathrm{T}-\mathrm{C} \\
(\%)\end{array}$ & $\begin{array}{c}\mathrm{T}-\mathrm{N} \\
(\%)\end{array}$ & $\mathrm{C} / \mathrm{N}$ & $\mathrm{pH}$ & $\begin{array}{c}\text { E. C. } \\
(\mathrm{mS} / \mathrm{cm})\end{array}$ & $\begin{array}{c}\text { Age } \\
\text { (months) }\end{array}$ & $\begin{array}{c}\text { CEC } \\
\text { (meq/100 g) }\end{array}$ \\
\hline Farm manure & 30.0 & 2.75 & 10.9 & 7.35 & 1.30 & 3 & 145.6 \\
Gum tragacanth & 39.1 & 0.07 & 558.0 & 4.45 & 0.60 & - & 102.1 \\
Com. manures* & 38.7 & 1.21 & 31.9 & 6.70 & 0.16 & 0 & - \\
Com. manures & 32.7 & 2.93 & 13.7 & 6.35 & 0.21 & 2 & - \\
Com. manures & 36.4 & 1.12 & 32.6 & 6.10 & 0.24 & 4 & 68.6 \\
Com. manures & 33.6 & 2.71 & 12.4 & 6.72 & 0.48 & 6 & - \\
Farm litter & 8.4 & 1.04 & 8.1 & 7.15 & 0.70 & 3 & 47.3 \\
Filter paper & 41.2 & 0.04 & 1030.0 & 6.80 & 0.00 & - & -
\end{tabular}

* Commercially available farm manures of various decomposition period (age).

Table 2 Some of properties of the inorganic materials used.

\begin{tabular}{lccc}
\hline \multicolumn{1}{c}{ Materials } & E. C. $(\mathrm{mS} / \mathrm{cm})$ & $\mathrm{pH}$ & CEC (meq/100 g) \\
\hline Top soil (volcanic ash) & 0.08 & 5.30 & 38.5 \\
Sub soil (volcanic ash) & 0.11 & 5.65 & 19.6 \\
Sub soil (brown forest) & 0.12 & 6.70 & 6.3 \\
Allophane soil (Kanuma) & 0.03 & 6.10 & 92.4 \\
Kaolin & 0.17 & 4.60 & 10.5 \\
Bentonite & 1.70 & 9.55 & 61.7 \\
Sand & 0.00 & 7.10 & 0.8 \\
\hline
\end{tabular}




\section{Seed germination tests}

The tests were carried out at $25^{\circ} \mathrm{C}$ in the dark, and the certified wheat (Norin No. 61) seeds were used for germination tests. Germination rate (\%) for each case was calculated as:

Table 3 Characteristics of the salt ( $\mathrm{NaCl})$ solutions used.

\begin{tabular}{ccc}
\hline Na conc. $(\mathrm{ppm})$ & E. C. $(\mathrm{mS} / \mathrm{cm})$ & $\mathrm{pH}$ \\
\hline 1000 & 4.5 & 5.80 \\
2000 & 8.9 & 5.65 \\
3000 & 13.0 & 5.40 \\
4000 & 17.0 & 5.20 \\
5000 & 20.8 & 5.10 \\
6000 & 25.0 & 5.10 \\
7000 & 29.0 & 5.10 \\
8000 & 34.0 & 5.00
\end{tabular}

E. C. and $\mathrm{pH}$ were measured at room temperature (about $25^{\circ} \mathrm{C}$ ).

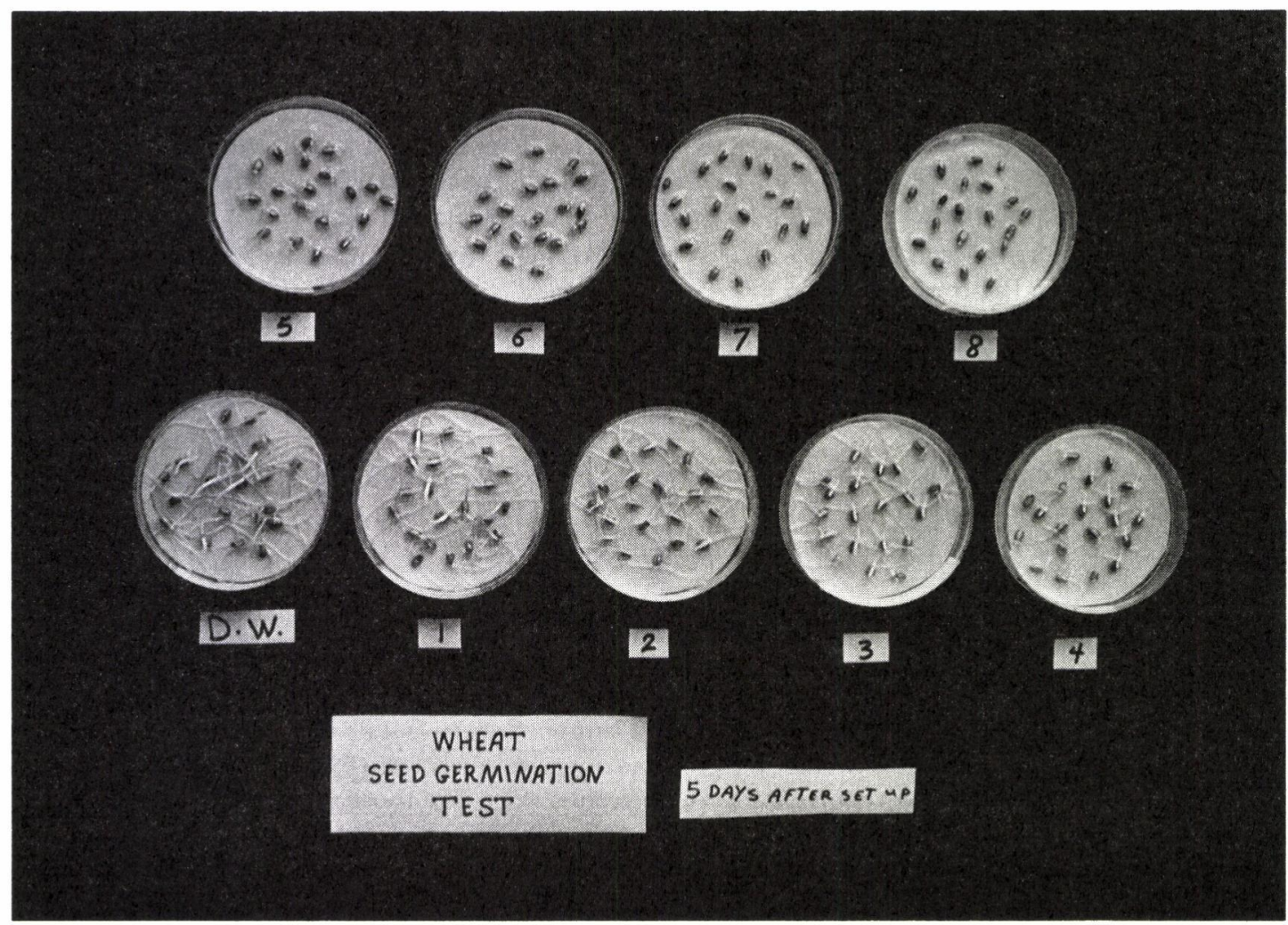

Photo. 1 Seed (wheat Norin No. 61) germination test under various salinity levels. D. W.: distilled water; $1,2,3,4,5,6,7,8 \times 1000 \mathrm{ppm}$ of Na. 


$$
\text { G. R. }(\%)=\frac{\text { No. of germinated seeds }}{\text { Total No. of seeds }} \times 100
$$

based on previous reports. ${ }^{6-8)}$

Germination tests for seeds under normal condition were carried out on filter paper sheets in $11 \mathrm{~cm}$ diameter petri dishes, 100 seeds per dish (duplicate) with $10 \mathrm{ml}$ water added to each dish.

To determine the most critical (lethal) level of $\mathrm{Na}$ concentration in which no germination occurs, seeds were subjected to salt solutions containing $0,1,2,3,4,5,6,7,8$ $\times 1000 \mathrm{ppm}$ of $\mathrm{Na}$ (Table 3). Twenty seeds were placed on each filter paper sheet within $9 \mathrm{~cm}$ diameter petri dishes (Photo. 1), with $5 \mathrm{ml}$ of salt solution added to each dish. The test was carried out for 5 days and each day the number of seeds germinated in each dish were recorded. The seeds were considered germinated when shoot reached $0.1 \mathrm{~cm}$ in length.

The further tests were carried out similarly, except seeds were placed on amending materials within petri dishes ( $2 \mathrm{~g}$ per dish) and supplied with solution containing critical level of $\mathrm{Na}$.

\section{Methods of chemical analysis}

At final stage of the germination tests, content of dishes was filtered and the "free" ions in filtrate were detected. To release and measure the ions which were "physically" held, the residue was washed with 2 times of $80 \%$ ethanol, and $\mathrm{Na}$ concentration of washing was measured. A suspension of the residue (dried): $1 \mathrm{M}$ ammonium acetate ( $\mathrm{pH} 7$ ) of $1: 10$ ratio was made, mechanically shaken for $1 \mathrm{~h}$, filtered and $\mathrm{Na}$ concentration of filtrate was determined. The detected ions were designated as "chemically" held ions. In all the cases the $\mathrm{Na}$ concentration was measured by atomic absorption spectrophotometer (model 170-30 of Hitachi Co.).

The electrical conductivity (E. C.) of materials was measured by handy E. C. meter (model PK-5 of DKK Co.). A suspension of sample: water of 1:5 ratio was made and just after $5 \mathrm{~min}$ its $\mathrm{E}$. C. was determined. After $1 \mathrm{~h}, \mathrm{pH}$ of the suspension was measured by $\mathrm{pH}$ meter (model TOA, HM-5BS).

The cation exchange capacity (CEC) of materials was determined by Bower et al.9) method.

Carbon and Nitrogen of materials were measured by NC analyser (Sumigraph NC80 of Sumitomo Co.).

In all the cases distilled water was used.

\section{RESULTS AND DISCUSSION}

Under normal condition seeds had $94.0 \%$ of germination rate (Fig. 1).

For seeds cultured on filter paper and supplied with solution containing more than 4000 ppm of $\mathrm{Na}$, unsatisfactory germination was observed (Fig. 2 and Photo. 1). Other investigators also reported the same result. ${ }^{4,10)}$ For those supplied with 8000 ppm of $\mathrm{Na}$ within the given time, absolutely no germination occurred (Photo. 1). This result indicated that the critical (lethal) level of $\mathrm{Na}$ concentration which restricts the germination of wheat seed (Norin No. 61) is $8000 \mathrm{ppm}$. Since wheat is a medium salt tolerant crop $^{11)}$ and seed in germinating stage is much more resistant than later growth stages, ${ }^{12}$ the germinating seed resisted salinity effects up to certain level 


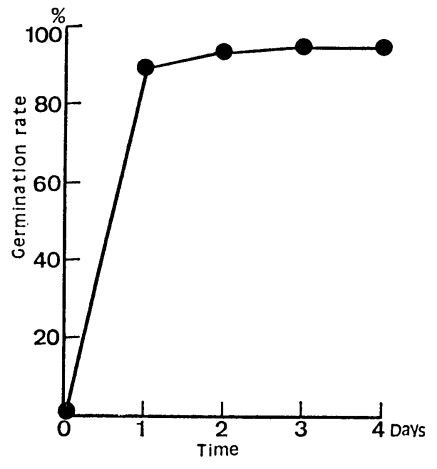

Fig. 1 Seed (wheat Norin No. 61) germination test under normal condition.

(4000 ppm). But as salt concentration increased their ability to withstand salinity stress decreased, with no germination occurring in concentration of $8000 \mathrm{ppm}$ $\mathrm{Na}$ (Fig. 2, Photo. 1). The salt induced effects are classified as: i) Nutritional effect-imbalance uptake of nutrients, ${ }^{13)}$ ii) Osmotic effect-causing a water deficit, ${ }^{14)}$ iii) Specific toxic effect - excessive accumulation of salt which lead to growth suppression. ${ }^{2)}$ Though in this study no attempt was made to separate these effects, overall results indicated that the germination and growth were suppressed by excess accumulation of ions on the external (plasma membrane) and/or internal system (protoplasm). Generally each salt concentration increment produced a corresponding drop in germination speed, germination rate, and seedling size (Figs. 2 and 3).

Table 4 shows the effect of organic amendments on seed germination and seedling growth of wheat cultured in highly saline environments. Contrary to control (filter paper), all treatments favored germination and growth. Farm manure, Gum tragacanth and commercial manure of 4 months decomposition period were the most beneficial. Commercial manures of 0,2 , and 6 months decomposition period and farm litter had less effect.

When Gum tragacanth came in contact with salt solution, it swelled and formed a gel. The water soluble portion (tragacanthin) which consists of glucuronic acids and arabinoses reacted with salt solution and formed sodium salts. ${ }^{15)}$ By such physicochemical mechanism it deactivated larger amount of ions which resulted in better 
Table 4 Effects of organic materials on seed germination and seedling growth of wheat cultured in saline environment.*

\begin{tabular}{lcc}
\hline Material used as seed bed & Germination rate $(\%)$ & Mean shoot length $(\mathrm{cm})$ \\
\hline Farm manure & 85 & 0.6 \\
Gum tragacanth & 90 & 0.3 \\
Com. manures 0** & 75 & 0.2 \\
Com. manures 2 & 65 & 0.3 \\
Com. manures 4 & 80 & 0.8 \\
Com. manures 6 & 60 & 0.3 \\
Farm litter & 35 & 0.1 \\
Filter paper & 00 & 0.0 \\
\hline
\end{tabular}

* Data for 5 th day of salinization period, in salt solution containing $8000 \mathrm{ppm}$ of $\mathrm{Na}$.

** Commercial manures of $0,2,4$, and 6 months decomposition period (age).

germination and seedling growth. $\mathrm{pH}$ of Gum tragacanth treated sample at final and initial stages of experiment was almost the same (data not shown) indicating that mostly $\mathrm{H}$ ion was released in the medium. This property of Gum can be applied to retain the $\mathrm{pH}$ of the growth medium at constant and desired level. While for other samples $0.6-1.3$ increase in $\mathrm{pH}$ value was recorded, suggesting that various ions were released in the media.

Germination rate of seeds cultured on Gum tragacanth treated sample was 5\% higher than that of farm manure treated. Considering the shoot length which is also a sensitive indicator of salinity stress, ${ }^{10)}$ the beneficial effects of manure were more significant.

Based on decomposition period (age factor) commercial manure of 4 months age showed better effect. Manures of 0 and 2 months age were immature and that of 6 months age was too decomposed and therefore they had poor physicochemical properties which resulted in low germination rate. These results suggest that the manures of 4 months age have better quality. Informations in the literatures ${ }^{16,17)}$ indicate that the 3-4 months age is appropriate time for manures to reach mature and stable stage.

The farm litter of Zelkova serrata had low CEC, and small surface area, and contained some amount of cellulose and lignin which reduced chemical reaction and formation of chemical bonds, therefore it had no significant effect on seed germination and seedling growth.

Filter paper (control) had no good physicochemical status to hold the ions, so salinity adversely affected the seeds, hence no germination occurred.

Of inorganic materials tested, Kanuma (allophane) soil having a higher cation exchange capacity (Table 2), hence larger surface area, showed better effect (Table 5). The toxic cation $(\mathrm{Na})$ was replaced by less toxic or non-toxic cations $(\mathrm{K}, \mathrm{Mg})$ held on the surface and/or within the framework of mineral, as a result salinity of the medium decreased, therefore higher germination rate and better growth were observed. Little, if any, $\mathrm{Al}$ ions might be released in the medium, but the solubility, activity and toxicity of $\mathrm{Al}$ are much lower than that of $\mathrm{Na}$. Generally $\mathrm{Al}$ ion depresses the photosynthesis, ${ }^{1)}$ so its adverse effects are serious in the light than in the shade.

Poor physical structure, low cation exchange capacity (Table 2), limited microbial 
Table 5 Effects of inorganic materials on seed germination and seedling growth of wheat cultured in saline environment.*

\begin{tabular}{lcc}
\hline Material used as seed bed & Germination rate $(\%)$ & Mean shoot length $(\mathrm{cm})$ \\
\hline Top soil (volcanic ash) & 60 & 0.1 \\
Sub soil (volcanic ash) & 85 & 0.2 \\
Sub soil (brown forest) & 40 & 0.1 \\
Allophane soil (Kanuma) & 80 & 0.3 \\
Kaolin & 00 & 0.0 \\
Bentonite & 00 & 0.0 \\
Sand & 00 & 0.0 \\
\hline
\end{tabular}

* Data for 5 th day of salinization period, in salt solution containing $8000 \mathrm{ppm}$ of $\mathrm{Na}$.

species and population are some of the factors which reduced the ion holding capability of the used sub soils. Such poor physicochemical properties caused low germination rate.

The high alkali reaction, and total salt content of bentonite masked its positive effect (CEC) hence seed germination was depressed by salinity and alkalinity effects.

Preventing the excess flow of ions into seedling through "ion holding mechanism" is one of the means by which the materials inhibited the salinity effects. When ions brought in contact with the materials, some formed chemical bonds, some were incorporated by existing microorganisms, ${ }^{1,18)}$ and others were retained in the net like structure of materials. The gumlike substance which is known as mucilage produced by microorganisms may also retained some ions in its framework. Through such biophysical mechanism the activity and damage of ions were reduced. Presence of salt resistant bacterial and fungi that can survive in salt saturated media is well documented. ${ }^{1,18)}$

The "effective" materials i.e. farm manure, Gum tragacanth, and commercial manure of 4 months decomposition period (organic materials), and Kanuma soil, top and sub forest soils (volcanic ash origin) of inorganic materials were studied in detail with particular references to their cation exchange capacity.

It was found that the materials held $25-45 \%$ of the added $\mathrm{Na}$ in their framework,

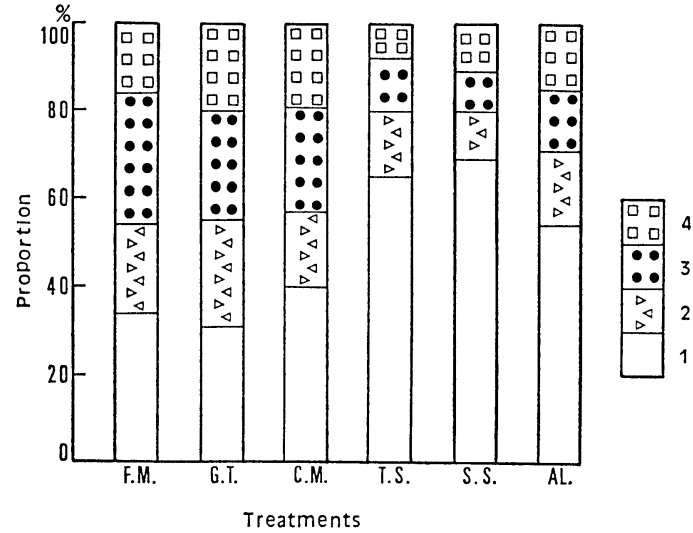

Fig. 4 Status of the added $\mathrm{Na}$ ions at final stage of the experiment. F. M., farm manure; G. T., Gum tragacanth; C. M., commercial manure of 4 month decomposition period; T. S. and S. S., top and sub forest soils of volcanic ash origin; Al., allophane rich soil (Kanuma). 1, Free ions; 2, ions held physically; 3 , ions held chemically; 4, undetected ions. 
in one way or another (Fig. 4). The farm manure (CEC, $145.6 \mathrm{meq} / 100 \mathrm{~g}$ ) held about $49.7 \%$ of $\mathrm{Na}$, of which $20 \%$ were "physically," and $29.7 \%$ "chemically" held, therefore had the highest (0.49) "treatment efficiency." Gum tragacanth held greater amount $(22.8 \%)$ of ion by "physical" action. This partly is attributed to gel formation ability of the gum. Sub soil having the smallest CEC (19.6 meq/100 g) held the lowest amount $(19.97 \%)$ of $\mathrm{Na}$, and its "treatment efficiency" was 0.20 . Generally the amount of Na held by each material was correlated to its CEC. This result indicated that the "ion holding" is the major mechanism by which the materials reduced the ion $(\mathrm{Na})$ damage.

Though the CEC of Kanuma soil was somewhat greater than that of commercial manure of 4 months decomposition period, the later one held larger amount of $\mathrm{Na}$. This might be partly due to biophysical properties of the manure.

Application of materials with higher cation exchange capacity (CEC), and better biophysical properties which deactivate larger amount of toxic ions is one of the means to reduce the salinity hazard without removing the salt from the salt affected soils.

The authors are grateful to the Ministry of Education, Science and Culture of Japanese government for providing scholarship and facilities, and to professor K. Ishihara, Y. Arima of Tokyo University of Agriculture and Technology for their valuable suggestions.

\section{REFERENCES}

1) Levitt, J. 1980. Responses of Plants to Environmental Stress 365-488, Academic Press, New York.

2) Tagawa, T., and N. Ishizaka. 1963. Physiological studies on the tolerance of rice plants to salinity. II. Effects of salinity on the absorption of water and of chloride ion. Proc. Crop Sci. Soc. Jpn. 31 : 337-341.

3) Kingsbury, R. W., E. Epstein, and R. W. Pearcy. 1984. Physiological responses to salinity in selected line of wheat. Plant Physiol. 74: 417-423.

4) George, L. Y. 1967. Accumulation of sodium and calcium by seedlings of some cereal crops under saline conditions. Agron. J. 59: 297-299.

5) Pearson, G. A., and L. Bernstein. 1958. Influence of exchangeable sodium on yield and chemical composition of plants. II. Wheat, barley, oats, rice, tall fescue, and tall wheatgrass. Soil Sci. 86: 254-261.

6) Aosa. 1976. Cool germination test. The Newsletter of the Association of Official Seed Analysts 50: 27-30.

7) McDonald, M. B. 1982. Germination testing. Agronomy 630: 18-23.

8) Nagao, M., M. Takahashi, and M. Suzuki. 1951. Nougaku Jikken Hou 48-56, Youken Dou, Tokyo (in Japanese).

9) Bower, C. A., R. F. Reitemeier, and M. Fireman. 1952. Exchangeable cation analysis of saline and alkali soils. Soil Sci. 73: 251-261.

10) Fogle, V. W., and D. N. Munns. 1973. Effects of salinity on the time course of wheat seedling growth. Plant Physiol. 51: 987-988.

11) Singh, K. S. 1982. Reclamation of salt affected soils. In “Agricultural Technology" (eds. by Menrota, H. N.) 18-21, University of Udaipur, India.

12) Ungar, I. A. 1974. The effects of salinity and temperature on seed germination and growth of Hordeum Jubatum. Can. J. Bot. 52: 1357-1362.

13) Kyuma, K. 1983. Productivity of lowland soils. In "Potential Productivity of Field Crops under Different Environments” (eds. by Swaminathan, M. S.) 438-439, International Rice Research Institute, Manila. 
14) Munns, R., and A. Termant. 1986. Whole-plant responses to salinity. Aust. J. Plant Physiol. 13: 143-160.

15) Whistler, R. L., and C. L. Smart. 1953. Polysaccharide Chemistry, 312-314. Academic Press, New York.

16) Asija, A. K., R. P. Pareek, R. A. Singhania, and S. Singh. 1984. Effects of method of preparation and enrichment on the quality of manure. J. Indian Soc. Soil Sci. 32: 323-329.

17) Saraswat, M. C. 1982. Organic manures. In "Agricultural Technology" (eds. by Mehrota, H. N.) 24-26, University of Udaipur, India.

18) Keller, P., and Y. Henis. 1967. The effect of yeast extract and casitone on the response to salt of the microflora of a highly saline soil. Can. J. Microbiol. 13: 1427-1432.

\section{〈和文抄録〉}

\section{塩性環境下における種子発芽に対する改良資材の効果 \\ G. SHOKOHIFARD · 坂 上寛一・浜田龍之介・松 本 聰* 東京農工大学農学部, *東京大学農学部}

塩類集積による植物生育阻害を緩和する方法の 1 つとして，塩類を吸着・保持不活性化する改良 資材を施用することが考兄られる。ここでは，実験室内において高浱度塩性環境下の種子発芽試験 により，種々の改良資材の効果について検討した，得られた結果は次のとおりである.

1. 資材無施用, $25^{\circ} \mathrm{C}, 5$ 日間培養時では，小麦（農林 61 号）はナトリウム濃度 $4000 \mathrm{ppm}$ で発 芽不良となり， $8000 \mathrm{ppm}$ ではまったく発芽しなかった。

2. 資材のあるものは塩による発芽阻害を軽減した。一般に，有機資材の効果が大であった。

3. 検討した資材のなかでは, 3〜4 カ月間熟成した厩肥，トラガカントガムおよびアロフェンに 富む土㙋が良好な軽減効果を示した。

4. 有効な資材は多量の $\mathrm{Na}$ イオンを保持し，不活性化することが明らかとなった。 